\title{
Error Analysis in Arabic Language among Engineering Student at Universiti Malaysia Pahang
}

\author{
Mohammad Baihaqi Bin Hasni ${ }^{1}$, Mardhiyyah Binti Zamani ${ }^{1}$ Shahrel Ahmad bin Shuhel Ahmad ${ }^{2}$ \\ ${ }^{1}$ Centre of Modern Language and Human Sciences, Universiti Malaysia Pahang, 26600 Kuantan, Pahang, \\ Malaysia \\ ${ }^{2}$ Centre of Research for Fiqh Science \& Technology (CFiRST) Ibnu Sina Institute for Scientific \& Industrial \\ Research (ISI-SIR) Block S45, c/o Kolej Tuanku Canselor 81310 UTM Johor Bahru, Johor Darul Ta'zim, \\ Malaysia
}

\begin{abstract}
This study aims to analyze the errors in Arabic Language among students who learn Arabic for Beginners course (UHF 1141) at the Universiti Malaysia Pahang. The study was carried out against the 30 students, who took Arabic for Beginners course, using their written test paper as data of the study. This analysis is adapted using the theory of Corder (1967). According to Corder (1981), the error or offense language is a form of the use of language that deviated from the language system received by the native speakers and the errors cover language aspect, such as grammar, spelling, pronunciation, word usage, term, etc. Study data is amplified with the questionnaire data carried out against 4 teachers and 30 students who attended the course. The findings show that students made the error in grammar, such as error in aspect, phrases, sentences and orthography of the word. The study also found that the orthography error, which is the spelling error is mostly committed by the students (54 errors). The second highest error is the error in word aspect, i.e. feminine and masculine (45 errors), followed by word aspect of Singular, duo and Plural (36 errors). The error in pronouns followed by (21 errors). The lowest error in terms of frequency is the error in the use of number aspect (15 errors). Based on the questionnaire, most students made grammar mistakes due to disruption of native language, the attitude of students and the language environment in university. To address this problem, language teaching and learning strategies should be increased. Continuous guidance from the teacher/lecturer, language learning through multimedia and organizing activities such as quizzes, acting and visit are essentials in encouraging Arabic language learning among foreign students.
\end{abstract}

Keywords: Arabic, error analysis, engineering student, teaching and learning.

\section{Introduction}

Students at the Universiti Malaysia Pahang (UMP) are obliged to choose the subject of Foreign Language as an optional subject to fulfil the credit hours required by the university. Baihaqi (2017) said there are several factors that influence the selection of Foreign Language subjects, especially the Arabic language, such as the students' background, peer influence, lack of information and relevancies of the language. The study found that some students who took Arabic language subject were students who had studied the Arabic when they were at their primary or secondary schools. At UMP, the Arabic language is taught based on the four elements of language proficiency namely Listening, Communication, Reading and Writing. However, for beginners, students are emphasized to master the elements of communication as opposed to the three elements mentioned. In the subject, students are taught the basics knowledge in Arabic language starting from recognizing the letters and writing the Arabic script. The syllabus used is compiled and processed according to the course outcome and the program outcome. During the 14 weeks of a semester period, students are expected to master the basic Arabic language skills. However, in the limited period of time, part of the students experienced difficulties to master the 
basic of the Arabic language especially those who have never learn the Arabic (Baihaqi, 2017). Baihaqi (2017) thinks the weakness to master the Arabic language is due to the weakness of mastering the Arabic vocabulary correctly. According to Corder in Tarigan (1990: 62), everyone who learns the language will not escape from making mistake. A mistake is indeed a source of inspiration to seek the truth. The study of mistakes and their relationship with language teaching should be encouraged since through an analysis of the mistakes, the language errors committed by the students can be corrected. Once the errors have been identified, they can be corrected with more effective teaching and learning techniques. Language error is a process based on an analysis of student mistakes or someone who is learning something, such as a foreign language. Ability to master a language can be done by learning it by repeatedly with correction. This learning process should use the right strategy to get the positive results. Language error analysis is aimed at the target language since the analysis can help to smooth teaching process, in which, with an error analysis the teachers can overcome the difficulties faced by the students. The error is usually determined based on the rules applied in the language that being studied. If the word or sentence used by the student is not in accordance with the applicable rules, then the student will make a mistake. According to Tarigan (1990: 68), the language error analysis is a work process used by the teachers and language researchers with data collection steps, identification of errors in data, explanation of the error and classification of the error based on the cause, and analyzing the seriousness of the error. Language errors often occur due to the learners' ability to understand language. Errors usually occur systematically. This type of error can occur over a long period of time when it is not fixed. Improvements made by teachers are usually through recovery, training, practical, etc. Sometimes it is often said that mistakes are a reflection of the students' understanding of the language system being studied. When the level of student understanding of the language learning system increases, it will reduce the students' error in the language. Vocabulary is an important asset in building Arabic learning. Baihaqi (2017) found that the UMP students' mastery level in Arabic Language was weak. According to Corder (1974), the error is 'significant', that is something that has certain meanings not only for the students but also for the researchers and teachers. Thus, this study is conducted specifically for researching and identifying grammatical errors and classifying the types of mistakes made by UMP students in learning Arabic. The districts of the student's error in the learning process can be avoided and help them obtain excellent results. The objects of error analysis are related to phonology, morphology, syntax, and semantic.

\section{Literature Review}

Analysis of language mistakes was a popular study. Some of the studies that have been done are (Khazri, Ku Siti Esah, 2012) which analyze the mistakes of writing in undergraduate students of the Faculty of Islamic Studies (FPI) who registered the PPPY 1132 Maharat al-Kitabah course. The study was conducted on 22 students using their essay writing under the title of the student's life, my family, the believer's prayer and the conversation about daily life as a study data. The findings of the study show that the students committed misconducts categorized as imla ', single, dual and plural singles, ishtiqaq selection, linguistic, muzakkar and muannath adjustment, ta'diyah and grammar selection. To address this problem, language teaching and learning strategies should be enhanced. Persistent guidance from teachers, language learning through multimedia and organizing language activities such as quizzes, acting and outdoors activities (co-curriculum) are essential in promoting Arabic language learning among FPI undergraduates. The authors are of the view that many researchers adapt Pit S Corder's theories and opinions in analyzing language errors. Among them are Saadah, (2016), Baharum \& Samah (2015) and Zakiah (2015). According to Pit S Corder, cited by Parera (1997), language errors are a form of deviation that is systematic, persistent, and characteristic of learners at a certain level. While Thu'aimah explained that:

$$
\text { الخطأ اللغوي هي صيغة لغوية تصدر من الطالب بشكل لا يوافق عليه المعلم وذلك لخالفة قواعد اللغة. }
$$

"Language mistakes are a form of student language that is not in line with the (instruction) of the teacher, as well as deviating from the language method." 
Meanwhile, error analysis is defined by Tarigan as follows: "A work procedure, commonly used by researchers and language teachers, which includes sample collection, identification of the errors found in the sample, the explanation of the error, the classification of the error based on the cause, and the evaluation or an appraiser between the seriousness of the offense". Meanwhile, according to Richards (1992), intralingual mistakes arise from wrong or incomplete learning in the second language as students have not mastered the target language such as "He made me to smile", "I want learning English" and "The meat smells freshly "(Bada, 2005). Richards (1992) also explained that students may made hypothesis that are not associated with their mother language or their second language. An Analysis of Language Errors examines the language of foreign students or second language learners, empirically testing the errors that exist in the target language generated by the students and seek explanations on the causes of the error (Arabic Language Teaching and Learning 2012). This is in line with Ellis (1994)'s opinion that the Analysis of Language Errors as, "... a set of procedures for identifying, describing and explaining error in learner's language." Corder (1967) explains that errors are important in three ways to the following groups: (i) instructor: they show student performance progress; (ii) researchers: they demonstrate ways of acquiring languages and strategies that students use; (iii) students: they can learn from these mistakes.

The findings from Azman \& Goh (2010) show that the main problem for students to learn Arabic is the Arabic grammar. When discussing language disorders, some mistakes occur due to the interruption in standard Arabic and some are derived from colloquial Arabic (Saadah, F, 2016). Although the findings in Saadah, F. (2016) found that students make mistakes because of their mother-tongue language disorders, but the most common mistake students do is intralingua mistake. Kamarulzaman Abdul Ghani (2011) study shows that the average score in measuring the readability of BATTE textbooks is $49 \%$, involving $96.47 \%$ of form four student respondents in SMKA in Malaysia. In Arabic writing skills, Suryadarma's study (2015) was agreed upon by Hamid, Yusof \& Rahimi (2014) that the students' achievement in the overall skill was moderate. These weaknesses cause them to fail in university Arabic courses. The study conducted by Abdullah \& David (2014) to students at UITM, JOHOR on the level of knowledge in building the Arabic language phrase, shows that only $10 \%$ of students are able to issue the sentence from the paragraphs given. Filzah Nawar (2011) found that 58\% students could not translate repeated words in politics, $70 \%$ of students could not translate repeated words in economics and $68 \%$ of students were unable to translate repeated words in sports. The author selected 32 students from the Islamic education program, Universiti Sains Islam Malaysia as a sample of the study. The study of Muhamad Hanan (2011) conducted on 30 Islamic Academic Studies, University of Malaya found that $60 \%$ of students agreed with the statement they fear of speaking Arabic due to language mistakes in constructing sentences. Hanani Hasan (2011) conducted a study on the final year students of the Faculty of Shariah and the Law, Universiti Sains Islam Malaysia (USIM), on the level of domination of Arabic vocabulary that are repeated in the field of Islamic studies.

\section{Research Methodology}

\subsection{Method}

The method used in this research is a descriptive method, which is a method that attempts to solve or answer problems encountered by collecting data, analyzing data and making conclusions and reports. The descriptive method is expected to help identify and analyze the language errors in the Arabic for Beginners examination paper.

The source of this research data is the Arabic Language written test paper of UMP engineering students in Semester 1 2016/2017. The study was conducted on 30 students who took the Arabic for Beginners course in Semester 1 2017/2017. The technique used to collect data in this research is a check and record technique. 


\subsection{Data Analysis Technique}

Data analysis is done by identifying the language errors. Once identified, these language errors are classified into specific groups so that language errors often made by the learner are seen. Here are the steps:

(i) Read and view the written answers. The obtained data through the written paper are read and understood one by one.

(ii) Classify the types of errors.

(iii) Analyzing grammatical and spelling errors.

(iv) Make a conclusion.

\section{Research Findings}

The findings from the study are as follows:

TABLE I: Arabic Language error

\begin{tabular}{llcc}
\hline \hline Type of error & & $\begin{array}{c}\text { Number of } \\
\text { error }\end{array}$ & Total \\
\hline \multirow{5}{*}{ Category } & $\begin{array}{l}\text { Orthography } \\
\text { Feminine \& }\end{array}$ & $54(32 \%)$ & \\
& $\begin{array}{l}\text { Masculine } \\
\text { Single, Duo }\end{array}$ & $35(26 \%)$ & \\
& \& Plural & $36(21 \%)$ & \\
& Pronouns & $21(12 \%)$ & \\
Number & $15(8 \%)$ & \\
\hline \hline
\end{tabular}

The total number of mistakes is 170 errors from 30 written test papers. Written test paper is divided into 3 tests.

- Listening test

- Reading Test

- Writing Test

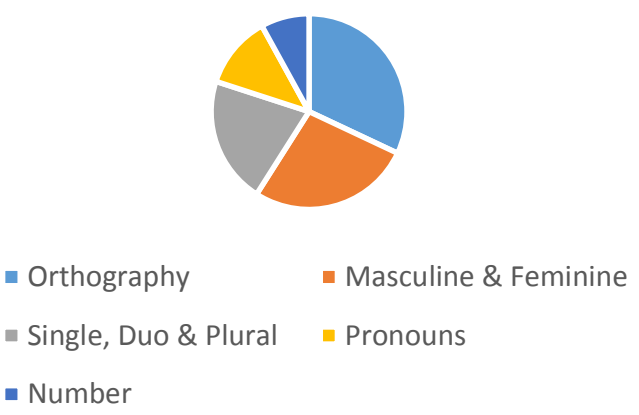

Fig. 1: Arabic language error

\section{Analysis \& Discussion}

Here are some examples of error correction together with the analysis.

The first error: error in spelling / orthography

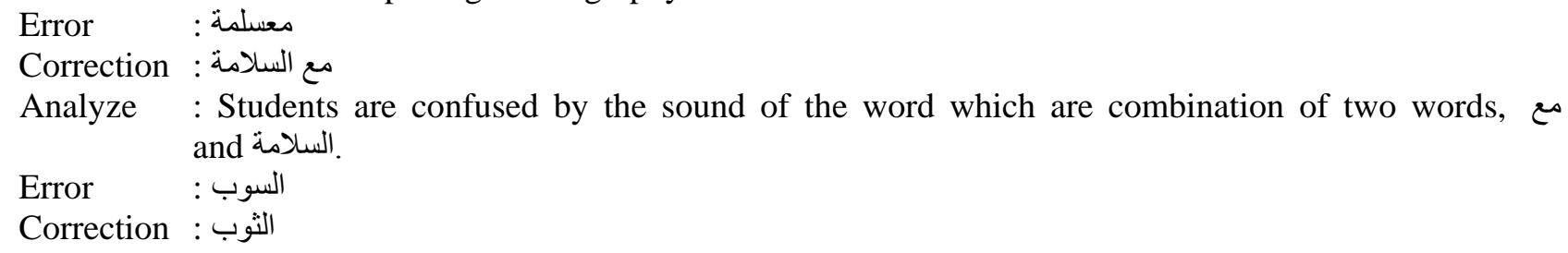


Analyze : Students are confused with the sound of the letters between the letters w and the letters $ث$.

Error : : :

اهلا وسهلا: : Correction

Analyze : Students are not confused with the sounds of nun nation.

Second error: error in the use of Masculine and Feminine

هذا عين : :

هذه عين : Correction

Analyze : is a woman lexical (pairing body) but has no feminine sign.

Third error: Error use of single, duo and plural.

Elror : :

خلفاء : Correction

Analyze : The Plural word for the lexical خلفاء is خليفة which is broken plural.

Learners are confused with plural types.

Fourth Error: Misuse of Pronouns

Eم قارعات القران :

Correction : هن قارءات القران :

Analyze : The student mistakenly puts the pronouns of man in the sentence which is reserve for pronouns of womens.

Fifth error: Error using number.

Error : : : الساعة الستة والستة وعشرون

Correction : الساعة السادسة و الستة و عشرونة :

Analyze : Students are confused with the use of Cardinal and Ordinal number.

\section{Conclusion}

This study is based on the problem of Arabic language proficiency among Universiti Malaysia Pahang engineering students. Based on the lexical error analysis, it was found that the orthographic errors/ spelling with vowel conversion with other vowels type and consonants with other consonants are the most committed by the students. The study shows that it is important to give attention to the grammar aspects in teaching and learning Arabic as a foreign/second language. The discovery of mistakes is a sign that multiple racial students need different emphasis or guidance. Consequently, this study is beneficial to the educators, the public and the media to help foreign speakers in learning Arabic. Students must be given the opportunity to speak in Arabic during their explanation, question or opinion. The use of reinforcing elements such as praise and rewards while teaching Arabic to increase their motivation to speak Arabic among fellow teachers, classmates or the community is encouraged. In addition, the preparation of methods, materials and activities when teaching Arabic to attract and improve the positive attitude among students to learn Arabic should also be emphasized. Indirectly, it is a good opportunity for students to be internationally accredited if they can communicate well in other languages.

\section{Acknowledgements}

This research is supported by the Universiti Malaysia Pahang under RDU 1703108. We are thankful to our CMLHS Dean and Head of Program Foreign Language Department who provided expertise that greatly assisted the research outcome.

\section{References}

[1] Mat, Azman Che, and Goh Ying Soon. "GRAMMAR IN THE CLASSROOM: STUDENTS'EXPECTATIONS AND REALITY THE CASE OF ARABIC AND MANDARIN." Novitas-Royal 4.1 (2010). 
[2] Baihaqi (January 2017). Contrastive Analysis of Gender (المذكر والمؤنث) in the use of Arabic and Malay Language Among Enggeering students of Universiti Malaysia Pahang. Journal of Global Business and Social Entrepreneurship (GBSE)Vol. 1: no.1(2017) page 100-109| Available: http://gbse.com.my/v1no1jan17/Paper-10-BM-.pdf

[3] Baihaqi, "Identifying the factors Contributing to Engineering Student's difficulties in Arabic Language Learning," presented at the ICTLL, April 04-04, 2017.

[4] Baihaqi (January 2017). M-Learning and its effects on learning Arabic as second language for engineering students. Journal of Humanities, Language, Culture and Business (HLCB) Vol. 1: no. 1 (2017) page 175-183| Available: http://www.icohlcb.com/images/Articles/Vol_1/Paper-018-.pdf

[5] Corder, Stephen Pit. Error analysis and interlanguage. Oxford Univ Pr, 1981.

[6] Filzah Nawar. Tarjumat kalimaat sahafiyyah lada talabah wa talibaat sanah thalithah bi jami'ah ulum islamiyyah maliziyyah.Projek Ilmiah. Fakulti Pengajian Bahasa Utama. Nilai: Universiti Sains Islam Malaysia (2011).

[7] Hanani Hasan. "Ma'rifah mufradaat fi maqalah islamiyyah lada talabah sanah rabi'ah kulliyyah syariah wa qanun fi jami'ah ulum islamiyyah maliziyyah li 'am dirasi 2010/2011”. Projek Ilmiah. Fakulti Pengajian Bahasa Utama. Nilai:Universiti Sains Islam Malaysia (2011).

[8] Muhamad Hanan. “Asbab khauf lada talabah jami’ah malaya fi kulliyyah islamiyyah fi muhadathah”. Projek Ilmiah. Fakulti Pengajian Bahasa Utama. Nilai: Universiti Sains Islam Malaysia (2011).

[9] Genc, Bilal, and Erdogan Bada. "Culture in language learning and teaching." The Reading Matrix 5.1 (2005).

[10] Corder, S. P. The significance of learners' errors. Dlm. J. C Richards (1992).

[11] Corder, S. P. The significance of learner's errors. IRAL-International Review of Applied Linguistics in Language Teaching, 5(1-4), 161-170 (1967)

https://doi.org/10.1515/iral.1967.5.1-4.161

[12] Ellis, Rod. The study of second language acquisition. Oxford University, 1994.

[13] Hamid, Hamid Norni, Nik Yusof, and Madya Dr Nik Mohd Rahimi. Kajian bentuk-bentuk kesalahan karangan bahasa arab murid tingkatan enam Sekolah Menengah Arab Laki-Laki Hassanal Bolkiah, Brunei Darussalam. Diss. UKM, 2014.

[14] Saadah, Fina. "Analisis kesalahan berbahasa dan peranannya dalam pembelajaran bahasa asing." Wahana Akademika: Jurnal Studi Islam dan Sosial 14.1 (2016).

[15] Baharum, Azlan Shaiful, and Rosni Samah. "Persepsi Pelajar Universiti Awam terhadap Kesalahan Bahasa Arab, Faktor Penyumbang dan Implikasi." Sains Humanika 6.1 (2015).

[16] Abdullah, Muhammad Rozman, and Derwina Binti Daud. "L001. Communication Apprehension among Non-Native Speakers of Arabic in UiTM Johor."

[17] Khazri Osman \& Ku Siti Esah Ku Ibrahim (2012). Presentes at National Conference Malaysia

[18] Pengajaran Dan Pembelajaran Bahasa Arab 2012 (PKEBAR'12), Universiti Kebangsaan Malaysia, 130-138.

[19] Suryadarma, Yoke. " "الدقارنة بين علم اللغة التقابلي وتحليل الأخطاء.LISANUDHAD.2015 2.1 2.1

[20] Parera, Jos Daniel. "Metodologi pembelajaran bahasa analisis kontrastif antarbahasa analisis kesalahan berbahasa." Edisi kedua. Jakarta: Erlangga (1997).

[21] Zakiah, Azza. "Astudy on grammatical error made by the first year students of IAIN Tulungagung in writing narrative text in academic year 2014/2015.'(2015)

[22] Tarbiyah, Ahmadi Ahmadi Sekolah Tinggi Ilmu. "Analisis Kontrastif dan Analisis Kesalahan dalam Pembelajaran Bahasa Arab sebagai Second Language."

[23] Richards, Jack C., Peter Tung, and Peggy Ng. "The culture of the English language teacher: A Hong Kong example." RELC journal 23.1 (1992): 81-102.

https://doi.org/10.1177/003368829202300106 
[24] Tarigan, Henry Guntur. "Teori Belajar Bahasa." (1990).

[25] Thu'aimah, Rusydi Ahmad, and Muhammd Sayyid Mannâ. "Manahij Tadris al-Lughah al-Arabiyah bi al-Ta'lim alAsasiy." Keiro: Dar al-Fikr al-Arabiy (1998).

[26] Ghani, Kamarulzaman Abdul. "Kebolehbacaan Buku Teks Bahasa Arab Tinggi Berasaskan Ujian Kloz Dalam Kalangan Pelajar Di SMKA." GEMA Online Journal of Language Studies 11.2 (2011). 